\title{
The Impact of Digital Patient Portals on Health Outcomes, System Efficiency, and Patient Attitudes: Updated Systematic Literature Review
}

Elettra Carini ${ }^{1 *}$, MD; Leonardo Villani ${ }^{1 *}$, MD; Angelo Maria Pezzullo ${ }^{1}, \mathrm{MD}, \mathrm{MSc}$; Andrea Gentili ${ }^{1}$, MD; Andrea Barbara $^{2,3}$, MD; Walter Ricciardi ${ }^{1}$, MD, MPH; Stefania Boccia ${ }^{1,4}$, MSc, PhD

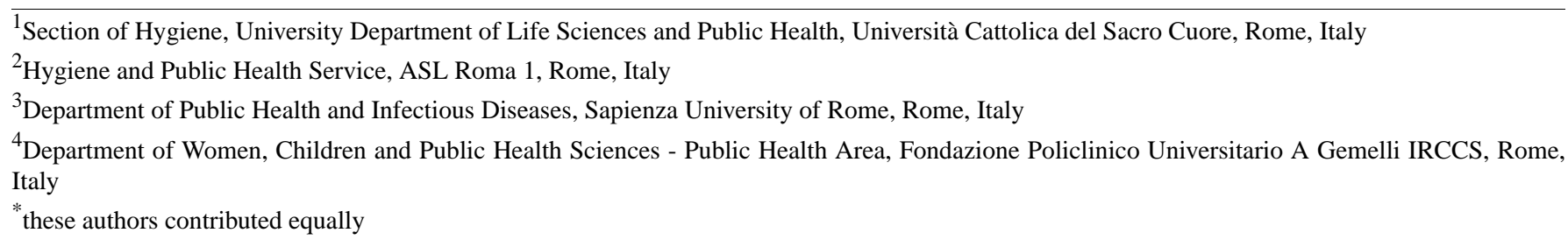

\section{Corresponding Author:}

Angelo Maria Pezzullo, MD, MSc

Section of Hygiene

University Department of Life Sciences and Public Health

Università Cattolica del Sacro Cuore

L go F Vito 1

Rome, 00168

Italy

Phone: 390630154396

Email: angelomaria.pezzullo01@icatt.it

\section{Abstract}

Background: Patient portals are becoming increasingly popular worldwide even though their impact on individual health and health system efficiency is still unclear.

Objective: The aim of this systematic review was to summarize evidence on the impact of patient portals on health outcomes and health care efficiency, and to examine user characteristics, attitudes, and satisfaction.

Methods: We searched the PubMed and Web of Science databases for articles published from January 1, 2013, to October 31, 2019. Eligible studies were primary studies reporting on the impact of patient portal adoption in relation to health outcomes, health care efficiency, and patient attitudes and satisfaction. We excluded studies where portals were not accessible for patients and pilot studies, with the exception of articles evaluating patient attitudes.

Results: Overall, 3456 records were screened, and 47 articles were included. Among them, 11 studies addressed health outcomes reporting positive results, such as better monitoring of health status, improved patient-doctor interaction, and improved quality of care. Fifteen studies evaluated the impact of digital patient portals on the utilization of health services with mixed results. Patient characteristics were described in 32 studies, and it was reported that the utilization rate usually increases with age and female gender. Finally, 30 studies described attitudes and defined the main barriers (concerns about privacy and data security, and lack of time) and facilitators (access to clinical data and laboratory results) to the use of a portal.

Conclusions: Evidence regarding health outcomes is generally favorable, and patient portals have the potential to enhance the doctor-patient relationship, improve health status awareness, and increase adherence to therapy. It is still unclear whether the use of patient portals improves health service utilization and efficiency.

(J Med Internet Res 2021;23(9):e26189) doi: $\underline{10.2196 / 26189}$

\section{KEYWORDS}

digital health; patient portal; health outcomes; patient satisfaction; patient attitudes; health service research; health care efficiency 


\section{Introduction}

In recent years, electronic tools that allow patients to interact with health care professionals have considerably increased with consequences on the awareness of citizens about their own health [1]. The adoption of these technologies might represent an important measure to improve the quality and efficiency of health care services and is a key feature for the construction of a more equitable, effective, and safe health care system [2]. Indeed, the rapid growth and diffusion of digital health, including health information sources, such as electronic medical records (EMRs), has made online access to information by patients and health care professionals a crucial component of health care delivery [3].

In this context, patient portals are thought to allow patients secure access to health-related information and to communicate and share information with providers [4]. Besides guaranteeing protected access to EMRs, more advanced patient portals allow secure message exchange between health professionals and citizens, consultation of educational material adapted to patients' own characteristics, appointment scheduling, automatic renewal of medical prescriptions for chronic diseases, and facilitation of payments. Despite their potential benefits, several studies have proved underuse or inappropriate use of patient portals and their limited impact [5]. Furthermore, the majority of studies available on this topic have focused on users' characteristics and satisfaction, and few studies have considered the consequences on health outcomes [6-8]. Patient portals are relatively new technologies with continuous updates. Several types are released every year, and this may explain the lack of research in this area [5].

A systematic literature review in 2013, which addressed the effect of patient portals on patient clinical care, reported that evidence was limited to evaluate whether patient portals had a positive, negative, or neutral impact on users' health [4]. Some of the most effective examples refer to patients with chronic diseases, such as diabetes, hypertension, and depression, specifically when the portal is included in a shared health care pathway [9-13]. The effect of patient portals on health care utilization and efficiency, instead, is unclear due to the scarcity of studies examining the impact of patient portals on key indicators, such as inpatient hospitalizations, emergency department (ED) and outpatient visits, length of stay, and telephone contacts [14]. The aim of this systematic review was to update the study performed in 2013 , by summarizing evidence on the impact of digital patient portals on patients' health outcomes, health care efficiency, and patients' attitudes and satisfaction.

\section{Methods}

\section{Search Strategy}

A search of relevant articles was performed in the PubMed and Web of Science databases using the query reported in Multimedia Appendix 1. The resulting records were entered in a dedicated work sheet to be subsequently screened according to the inclusion/exclusion criteria. Following the removal of duplicates, the selection was made by reading titles and abstracts, and then the full texts.

\section{Inclusion/Exclusion Criteria}

Eligible studies were primary studies reporting on the impact of patient portal adoption in relation with health outcomes, health care efficiency, and patients' attitudes and satisfaction. Articles included were published from January 1, 2013, to October 31, 2019, and written in English, Italian, Spanish, or French. We excluded studies describing portals that were not accessible for patients, as well as pilot studies, with the exception of studies evaluating patients' attitudes.

\section{Selection Process and Data Extraction}

Two authors screened the articles, and each reference retrieved was screened by two researchers independently, with any disagreement finally discussed and resolved by a third researcher, if necessary. The following information was extracted from the studies: first author name, publication year, study country, study design, study population, study setting, study duration and time, health information technology, study objective, main findings according to health outcomes, health care efficiency/utilization, patient characteristics, and patient attitudes and satisfaction. The systematic literature review was conducted according to the PRISMA (Preferred Reporting Items for Systematic Reviews and Meta-Analyses) 2009 checklist [15].

\section{Results}

\section{Characteristics of the Included Studies}

The database search, after duplicate removal, identified a total of 3456 records. According to the inclusion/exclusion criteria, the screening resulted in the inclusion of 47 full-text articles (Figure 1).

The study designs were grouped into six categories according to the characteristics of the articles. Overall, 17 were descriptive quantitative studies [8,16-31], two were descriptive mixed-methods studies [32,33], 14 were observational hypothesis testing studies [20,34-46], seven were descriptive qualitative studies [47-53], five were interventional studies, other than randomized controlled trials (RCTs) [54-58], and three were RCTs [59-61].

With regard to country, $33(70 \%)$ studies were based in the United States [17,18,20,21,31,32,34,43-46,49,60], three in Canada $[35,36,50]$, three in the Netherlands $[19,26,57]$, two in Finland [55,56], two in the United Kingdom [16,48], one in Australia [22], one in France [59], one in Israel [47], and one in Sweden [24].

Various patient portals have been described in the studies. Multimedia Appendix 2 provides details on the functionalities of the portals, and Multimedia Appendix 3 provides qualitative descriptions of the portals.

Most of the portals were not addressed to a defined population subgroup, and only some of them were specific to a clinical specialty/condition, such as endocrinology-diabetes $[8,21,26,34,36,41]$, primary care $[33,37,38,40,60]$, mental health 
[31,35,54], multiple chronic conditions [40,55,56], pulmonology and asthma [32,44,60], rheumatology [50,57,59], cardiology $[37,44]$, internal medicine [40,61], nephrology [30,46], pregnancy [34], cancer [53], and gastroenterology [48].

The population included in the studies was heterogeneous in terms of sample size (from 24 [52] to 2,171,325 patients [31]) and groups of included patients (eg, pediatric [32], older [31], oncology [52], and diabetic patients [60]).
The results were summarized in four categories, albeit the same study could belong to more than one category. In particular, 11 studies analyzed health outcomes and adherence, intended as a change in individual or population health, attributable to health-related interventions. Adherence is the degree to which a patient follows medical advice, especially drug compliance. Overall, 15 studies focused on health care efficiency/utilization (utilization of health care services), 32 studies referred to patient characteristics, and 30 studies analyzed attitudes and satisfaction.

Figure 1. PRISMA (Preferred Reporting Items for Systematic Reviews and Meta-Analyses) flow diagram.

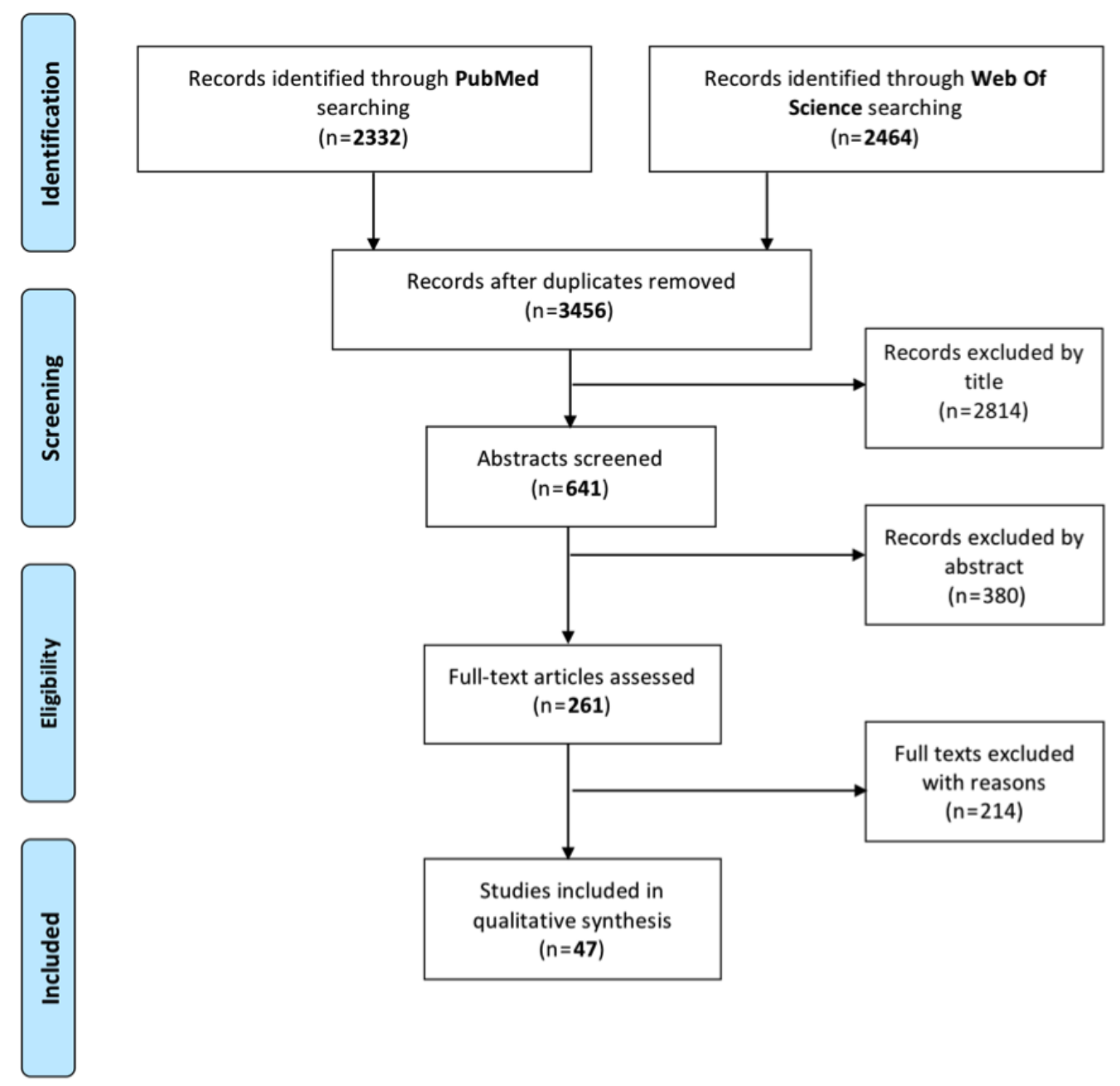

\section{Health Outcomes and Adherence}

Eleven articles presented results on patient outcomes (Table 1), such as prevention, diabetes, blood pressure control, asthma, mental health, and medication adherence.

In particular, a significant association was found between patients' preventive health behaviors and portal use [45]. Considering diabetes [34,36] and blood pressure control [37], portal users were significantly more likely to control their $\mathrm{HbA}_{1 \mathrm{c}}$ levels successfully compared to nonusers.

An improved clinical condition over time was observed in the management of asthma in children, where the group using the patient portal reported better flare control compared to the control group [60].

Concerning mental health, patients using the portal had a positive impact related to the clinical condition in many domains [35], such as the reduction of drinking days [54]. However, concerning the health status, no marked short-term impact was described, and differences in patient-reported physical and mental health changes were minor [55].

Finally, higher medication adherence was described in portal users compared with nonusers, especially among pediatric patients with asthma and patients with rheumatic disorders $[32,57]$. 
Table 1. Summary of the findings on health outcomes and adherence.

\begin{tabular}{|c|c|c|c|c|c|}
\hline $\begin{array}{l}\text { First author, } \\
\text { year }\end{array}$ & Country & $\begin{array}{l}\text { Health information } \\
\text { technology }\end{array}$ & Study design & Sample size & Main findings \\
\hline \multirow[t]{2}{*}{$\begin{array}{l}\text { Ancker, } \\
2019 \text { [34] }\end{array}$} & \multirow[t]{2}{*}{$\begin{array}{l}\text { United } \\
\text { States }\end{array}$} & \multirow{2}{*}{$\begin{array}{l}\text { Blood glucose flow } \\
\text { sheet (EpicCare } \\
\text { and Weill Cornell } \\
\text { Connect portal) }\end{array}$} & \multirow[t]{2}{*}{$\begin{array}{l}\text { Observational, } \\
\text { hypothesis testing }\end{array}$} & \multirow[t]{2}{*}{53 patients } & $\begin{array}{l}\text { Pregnant: average BMI dropped while average blood } \\
\text { pressure increased significantly more in the } 9 \text { months } \\
\text { among uploaders than nonuploaders. }\end{array}$ \\
\hline & & & & & $\begin{array}{l}\text { Chronic disease patients: after } 9 \text { months, uploaders had } \\
\text { significantly larger reductions in } \mathrm{HbA}_{1 \mathrm{c}} \text { and BMI than } \\
\text { nonuploaders. One subset of uploaders had low well-con- } \\
\text { trolled } \mathrm{HbA}_{1 \mathrm{c}} \text { values before and during PGHD }{ }^{\mathrm{a}} \text { upload. } \\
\text { Another uploader subset began to upload when their } \mathrm{HbA}_{1 \mathrm{c}} \\
\text { levels were elevated and experienced a decrease in } \mathrm{HbA}_{1 \mathrm{c}} \\
\text { levels followed by a plateau. }\end{array}$ \\
\hline
\end{tabular}

\begin{tabular}{|c|c|c|c|c|}
\hline $\begin{array}{l}\text { Fiks, } 2015 \\
{[60]}\end{array}$ & $\begin{array}{l}\text { United } \\
\text { States }\end{array}$ & $\begin{array}{l}\text { MyAsthma (clini- } \\
\text { cal interface in } \\
\text { MyChart) }\end{array}$ & $\mathrm{RCT}^{\mathrm{t}}$ & $\begin{array}{l}60 \text { families of } \\
\text { children }\end{array}$ \\
\hline
\end{tabular}

No significant differences in baseline control, quality of life, or parent activation between the two study arms $(P>.2$ for all comparisons). Frequency of asthma flares improved in the intervention group over time by 2.0 points on a 25 point scale $(P=.02)$. Families in the intervention group had a marginally significant improvement in symptoms during periods without flares. A nonstatistically significant improvement in quality of life in terms of daytime symptoms and functional limitations was observed in the intervention group. There were no significant changes in parent activation.

\begin{tabular}{|c|c|c|c|c|}
\hline $\begin{array}{l}\text { Fiks, } 2016 \\
{[32]}\end{array}$ & $\begin{array}{l}\text { United } \\
\text { States }\end{array}$ & MyAsthma & $\begin{array}{l}\text { Descriptive, } \\
\text { mixed methods }\end{array}$ & 237 families \\
\hline $\begin{array}{l}\text { Huang, } 2019 \\
{[45]}\end{array}$ & $\begin{array}{l}\text { United } \\
\text { States }\end{array}$ & $\begin{array}{l}\text { MyPennMedicine } \\
\text { (branded version of } \\
\text { Epic MyChart) }\end{array}$ & $\begin{array}{l}\text { Observational, } \\
\text { hypothesis testing }\end{array}$ & 10,000 patients \\
\hline
\end{tabular}

Portal users with uncontrolled asthma had significantly more medication changes after using the portal relative to the year earlier (increase of $14 \%$ ).

Patients' preventive health behaviors were significantly associated with portal use. The proportions of annual flu vaccination, blood pressure checks, and lipid level screening were substantially higher in portal users compared with nonusers $\left(\mathrm{OR}^{\mathrm{c}}=1.58,1.13\right.$, and 1.50 , respectively; $\left.P<.001\right)$. The average composite prevention score was significantly higher among portal users compared with nonusers (mean difference $=0.22 ; P<.001)$. The proportion of colorectal cancer screening between users and nonusers was statistically significant $(P<.001$, OR very close to 1$)$. No clinically meaningful difference between patient portal users and nonusers in chronic health outcomes.

$\begin{array}{ll}\text { Jhamb, } 2015 & \text { United } \\ {[46]} & \text { States }\end{array}$

Kipping, Canada 2016 [35]

Ontario Shores HealthCheck Patient Portal

Lau, 2014 Canada [36] tethered to an ambulatory EHR ${ }^{\mathrm{d}}$
Free patient portal

Observational, hypothesis testing

1098 patients

Inthe fully adjusted model (controlling fo

In the fully adjusted model (controlling for hyperlipidemia, nephrolithiasis, history of kidney transplant, $\mathrm{CCI}^{\mathrm{e}}$, proteinuria, $\mathrm{GFR}^{\mathrm{f}}$, number of nephrology and outpatient visits, and university affiliated $\mathrm{PCP}^{\mathrm{g}}$ ), the association was not significant (OR 1.11, 95\% CI 0.99-1.24).

The overall Mental Health Recovery Measure score increased from 70.4 (SD 23.6) at baseline to 81.7 (SD 25.1) at follow-up $(P=.01)$. Of the eight domains, seven increased from baseline to follow-up (overcoming stuckness, selfempowerment, basic functioning, overall well-being, new potentials, spirituality, and advocacy/enrichment; all $P<.05$. No change for learning and self-redefinition).

Overall, 28 of 50 users had a follow-up $\mathrm{HbA}_{1 \mathrm{c}} \leq 7 \%$, whereas 22 of $50 \mathrm{did}$ not ( $56 \%$ success rate).

Only 16 of 50 nonusers achieved a follow-up $\mathrm{HbA}_{1 \mathrm{c}} \leq 7 \%$, while 34 of 50 did not ( $32 \%$ success rate).

Users were significantly more likely to control their $\mathrm{HbA}_{1 \mathrm{c}}$ levels successfully than nonusers (McNemar test, $P=.03$ ). The $\mathrm{HbA}_{1 \mathrm{c}}$ level at the last follow-up was significantly lower for users compared to nonusers $(P=.02)$. 


\begin{tabular}{|c|c|c|c|c|c|}
\hline $\begin{array}{l}\text { First author, } \\
\text { year }\end{array}$ & Country & $\begin{array}{l}\text { Health information } \\
\text { technology }\end{array}$ & Study design & Sample size & Main findings \\
\hline $\begin{array}{l}\text { Manard, } \\
2016[37]\end{array}$ & $\begin{array}{l}\text { United } \\
\text { States }\end{array}$ & $\begin{array}{l}\text { Online patient por- } \\
\text { tal }\end{array}$ & $\begin{array}{l}\text { Observational, } \\
\text { hypothesis testing }\end{array}$ & 1571 patients & $\begin{array}{l}\text { After adjusting for age, users were more likely to achieve } \\
\mathrm{BP}^{\mathrm{h}} \text { control }\left(\mathrm{HR}^{\mathrm{i}} 1.24,95 \% \mathrm{CI} 1.06-1.45\right) \text {. After adjustment } \\
\text { for sociodemographics, portal use was no longer associated } \\
\text { with } \mathrm{BP} \text { control (HR } 0.98,95 \% \text { CI } 0.83-1.16) \text {. }\end{array}$ \\
\hline $\begin{array}{l}\text { Quanbeck, } \\
2018[54]\end{array}$ & $\begin{array}{l}\text { United } \\
\text { States }\end{array}$ & Seva & $\begin{array}{l}\text { Interventional, } \\
\text { other than RCT }\end{array}$ & 268 patients & $\begin{array}{l}\text { Significant reductions in the numbers of risky drinking } \\
\text { days, which declined by } 44 \%([0.7-1.25] / 1.25) \text { from base- } \\
\text { line to } 6 \text { months, and illicit drug-use days, which declined } \\
\text { by } 34 \% \text { ([2.14-3.22]/3.22). Two of the three abstinence } \\
\text { outcomes showed significant improvements (any illicit } \\
\text { drug use and/or any drink or drug). Significant effects were } \\
\text { found for two of the three quality of life scores (overall } \\
\text { quality of life and mental health). }\end{array}$ \\
\hline $\begin{array}{l}\text { Riippa, } 2015 \\
{[55]}\end{array}$ & Finland & $\begin{array}{l}\text { Patient portal by } \\
\text { The Finnish Medi- } \\
\text { cal Society, } \\
\text { Duodecim }\end{array}$ & $\begin{array}{l}\text { Interventional, } \\
\text { other than RCT }\end{array}$ & 876 patients & $\begin{array}{l}\text { Minor differences in patient-reported physical and mental } \\
\text { health changes that changed the sign from the matched } \\
\text { (physical health mean }=1.2,95 \% \mathrm{CI}-3.3 \text { to } 5.7 \text {; mental } \\
\text { health mean }=0.8,95 \% \mathrm{CI}-3.6 \text { to } 5.2 \text { ) to the unmatched } \\
\text { sample (physical health mean }=-0.4,95 \% \mathrm{CI}-4.7 \text { to } 3.9 \text {; } \\
\text { mental health mean }=-0.4,95 \% \mathrm{CI}-4.8 \text { to } 4.0 \text { ). Patient } \\
\text { activation improved more in the intervention group, but it } \\
\text { was not statistically significant. There was no marked short- } \\
\text { term impact on health status based on the SF-36v2 measure. }\end{array}$ \\
\hline $\begin{array}{l}\text { Van der } \\
\text { Vaart, } 2014 \\
{[57]}\end{array}$ & Netherlands & $\begin{array}{l}\text { Medisch Spectrum } \\
\text { Twente }\end{array}$ & $\begin{array}{l}\text { Interventional, } \\
\text { other than RCT }\end{array}$ & 360 patients & $\begin{array}{l}\text { Overall, } 56 \% \text { of the respondents had a score of } 7 \text { (out of } \\
8 \text { ) on medication adherence. }\end{array}$ \\
\hline
\end{tabular}

${ }^{\mathrm{a}}$ PGHD: patient-generated health data.

${ }^{\mathrm{b}} \mathrm{RCT}$ : randomized controlled trial.

${ }^{\mathrm{c}} \mathrm{OR}$ : odds ratio.

${ }^{\mathrm{d}}$ EHR: electronic health record.

${ }^{\mathrm{e}} \mathrm{CCI}$ : Charlson Comorbidity Index.

f eGFR: estimated glomerular filtration rate.

${ }^{\mathrm{g}} \mathrm{PCP}$ : primary care practice.

${ }^{\mathrm{B}} \mathrm{BP}$ : blood pressure.

${ }^{\mathrm{i}} \mathrm{HR}$ : hazard ratio.

\section{Efficiency/Utilization}

Fifteen articles described the relationship between portal use and health care service efficiency and utilization (Table 2). The use of a digital portal had an effect on the utilization of health

care services in terms of the number of clinical visits, especially for asthmatic patients [32,60], while no statistically significant changes in the number of primary care visits was reported in association with the use of secure messaging [38]. 
Table 2. Summary of the findings on health care efficiency.

\begin{tabular}{|c|c|c|c|c|c|}
\hline $\begin{array}{l}\text { First author, } \\
\text { year }\end{array}$ & Country & $\begin{array}{l}\text { Health information } \\
\text { technology }\end{array}$ & Study design & Sample size & Main findings \\
\hline $\begin{array}{l}\text { Ancker, } \\
2019[34]\end{array}$ & $\begin{array}{l}\text { United } \\
\text { States }\end{array}$ & $\begin{array}{l}\text { Blood glucose flow } \\
\text { sheet (EpicCare } \\
\text { and Weill Cornell } \\
\text { Connect portal) }\end{array}$ & $\begin{array}{l}\text { Observational, } \\
\text { hypothesis testing }\end{array}$ & 53 patients & $\begin{array}{l}\text { Uploaders had more clinical visits and portal logins before } \\
\text { initial data upload. }\end{array}$ \\
\hline $\begin{array}{l}\text { Bidmead, } \\
2016 \text { [48] }\end{array}$ & $\begin{array}{l}\text { England } \\
\text { (United } \\
\text { Kingdom) }\end{array}$ & $\begin{array}{l}\text { Patients Know } \\
\text { Best (PKB) }\end{array}$ & $\begin{array}{l}\text { Descriptive, qual- } \\
\text { itative }\end{array}$ & 56 patients & $\begin{array}{l}\text { The portal enabled clinicians to manage stable patients, } \\
\text { facilitating clinical and cost-effective use of specialist } \\
\text { nurses, and improved two-way communication and more } \\
\text { optimal use of outpatient appointments and consultant time. } \\
\text { It also facilitated a single rationalized pathway for stable } \\
\text { patients, enabling access to information and proactive } \\
\text { support. }\end{array}$ \\
\hline $\begin{array}{l}\text { Fiks, } 2015 \\
{[60]}\end{array}$ & $\begin{array}{l}\text { United } \\
\text { States }\end{array}$ & $\begin{array}{l}\text { MyAsthma (clini- } \\
\text { cal interface in } \\
\text { MyChart) }\end{array}$ & $\mathrm{RCT}^{\mathrm{a}}$ & $\begin{array}{l}60 \text { families of } \\
\text { children }\end{array}$ & $\begin{array}{l}\text { The intervention group had a marginally significant reduc- } \\
\text { tion in the proportion of parents missing at least } 1 \text { day of } \\
\text { work (reduction of } 47 \%, P=.07 \text { ). Families in the interven- } \\
\text { tion group reported fewer } \mathrm{ED}^{\mathrm{b}} \text { visits and hospitalizations } \\
\text { for asthma over } 6 \text { months than the control group ( } 3 \text { vs } 9 \\
\text { and } 0 \text { vs } 2 \text {, respectively). Only two intervention families } \\
\text { reported at least one ED visit (vs six control families), and } \\
\text { no intervention families reported hospitalizations. Children } \\
\text { in the intervention group had fewer visits with asthma } \\
\text { specialists or primary care. Results were similar on strati- } \\
\text { fying by asthma severity. }\end{array}$ \\
\hline $\begin{array}{l}\text { Fiks, } 2016 \\
{[32]}\end{array}$ & $\begin{array}{l}\text { United } \\
\text { States }\end{array}$ & MyAsthma & $\begin{array}{l}\text { Descriptive, } \\
\text { mixed methods }\end{array}$ & 237 families & $\begin{array}{l}\text { Portal users with uncontrolled asthma had significantly } \\
\text { more primary care asthma visits after using the portal than } \\
\text { the year earlier (increases of } 16 \% \text { ). }\end{array}$ \\
\hline $\begin{array}{l}\text { Foster, } 2019 \\
\text { [43] }\end{array}$ & $\begin{array}{l}\text { United } \\
\text { States }\end{array}$ & Epic MyChart & $\begin{array}{l}\text { Observational, } \\
\text { hypothesis testing }\end{array}$ & 208,635 tests & $\begin{array}{l}\text { ED visits: } 80.56 \%(\mathrm{n}=20,430) \text { of patients had a single } \mathrm{ED} \\
\text { visit with laboratory testing, } 16.04 \%(\mathrm{n}=4069) \text { had two or } \\
\text { three } \mathrm{ED} \text { visits, } 3.16 \%(\mathrm{n}=802) \text { had four to } 10 \mathrm{ED} \text { visits, } \\
\text { and only } 0.24 \%(\mathrm{n}=60) \text { had more than } 10 \mathrm{ED} \text { visits. Acti- } \\
\text { vation rates were lower for those with only a single } \mathrm{ED} \\
\text { visit }(7312 / 20,430,35.79 \%) \text { compared with either those } \\
\text { with two to three } \mathrm{ED} \text { visits }(1770 / 4069,43.50 \% ; P<.001) \\
\text { or four or more ED visits }(368 / 862,42.7 \% ; P<.001) \text {. }\end{array}$ \\
\hline $\begin{array}{l}\text { Griffin, } 2016 \\
\text { [44] }\end{array}$ & $\begin{array}{l}\text { United } \\
\text { States }\end{array}$ & My UNC Chart & $\begin{array}{l}\text { Observational, } \\
\text { hypothesis testing }\end{array}$ & 2975 patients & $\begin{array}{l}\text { The odds of being readmitted within } 30 \text { days for active } \\
\text { users was } 66 \% \text { higher than that for nonusers, holding all } \\
\text { other variables constant in the model. There was no signif- } \\
\text { icant difference in } 30 \text {-day readmission between nonusers } \\
\text { and light users. }\end{array}$ \\
\hline $\begin{array}{l}\text { Jahn, } 2018 \\
\text { [49] }\end{array}$ & $\begin{array}{l}\text { United } \\
\text { States }\end{array}$ & My HealtheVet & $\begin{array}{l}\text { Descriptive, qual- } \\
\text { itative }\end{array}$ & 29 participants & $\begin{array}{l}\text { Secure messaging tasks were inefficient as related to clini- } \\
\text { cal document sharing (it took almost } 5 \text { minutes for } \\
\text { providers to only attach and send a clinical document). }\end{array}$ \\
\hline $\begin{array}{l}\text { Kipping, } \\
2016[35]\end{array}$ & Canada & $\begin{array}{l}\text { Ontario Shores } \\
\text { HealthCheck Pa- } \\
\text { tient Portal }\end{array}$ & $\begin{array}{l}\text { Observational, } \\
\text { hypothesis testing }\end{array}$ & 91 patients & $\begin{array}{l}\text { Fewer missed appointments and a reduced number of re- } \\
\text { quests for information in the year following portal imple- } \\
\text { mentation. The odds of a portal user attending an appoint- } \\
\text { ment were } 67 \% \text { (CI } 56 \%-79 \% \text { ) greater than for nonusers } \\
\text { over the follow-up period. Compared with } 2014 \text {, in } 2015 \text {, } \\
\text { there was an } 86 \% \text { and } 57 \% \text { decrease in requests for infor- } \\
\text { mation among users and nonusers, respectively ( } 61 \% \\
\text { overall). }\end{array}$ \\
\hline $\begin{array}{l}\text { North, } 2014 \\
{[38]}\end{array}$ & $\begin{array}{l}\text { United } \\
\text { States }\end{array}$ & $\begin{array}{l}\text { Mayo Clinic } \\
\text { Health System }\end{array}$ & $\begin{array}{l}\text { Observational, } \\
\text { hypothesis testing }\end{array}$ & $\begin{array}{l}2357 \text { primary } \\
\text { care patients }\end{array}$ & $\begin{array}{l}\text { Primary care patients who sent at least one secure message } \\
\text { or e-visit had a mean of } 2.43 \text { (SD 2.3) annual face-to-face } \\
\text { visits before the first message and 2.47 (SD 2.8) after, with } \\
\text { a nonsignificant difference ( } P=.45 \text { ). After adjustment for } \\
\text { a first message surge in visits, no significant visit frequency } \\
\text { differences were observed (mean, } 2.35 \text { annual visits per } \\
\text { patient both before and after the first message; } P=.93 \text { ). } \\
\text { Subgroup analysis showed no significant change in visit } \\
\text { frequency for patients with higher message utilization or } \\
\text { for those who had used the messaging feature longer. }\end{array}$ \\
\hline
\end{tabular}




\begin{tabular}{lllll}
\hline $\begin{array}{l}\text { First author, } \\
\text { year }\end{array}$ & Country & $\begin{array}{l}\text { Health information } \\
\text { technology }\end{array}$ & Study design & Sample size \\
\hline $\begin{array}{l}\text { Plate, } 2019 \\
{[39]}\end{array}$ & $\begin{array}{l}\text { United } \\
\text { States }\end{array}$ & $\begin{array}{l}\text { MyChart; Epic } \\
\text { Systems Corpora- } \\
\text { tion }\end{array}$ & $\begin{array}{l}\text { Observational, } \\
\text { hypothesis testing }\end{array}$ & 6426 patients \\
& & &
\end{tabular}

Main findings

year tion

Active MyChart status was not associated with 90-day ED return $(P=.78)$ or readmission $(P=.51)$ based on univariable analysis. Similarly, during multivariable analysis controlling for age, gender, BMI, and $\mathrm{ASA}^{\mathrm{c}}$ category, active MyChart utilization was not significantly associated with 90day ED visits $\left(\mathrm{OR}^{\mathrm{d}} 1.019,95 \% \mathrm{CI} 0.843-1.231 ; P=.85\right)$ or readmissions (OR 0.966, 95\% CI 0.747-1.249; $P=.79$ ). Patients who sent secure messages within 90 days from surgery (2200 patients, $48 \%$ of active users) were not less likely to present to the $\operatorname{ED}(P=.63)$ or be readmitted $(P=.59)$ within 90 days. For patients who sent two or more messages (1354 patients), provider or staff response rate $<75 \%$ was significantly associated with 90 -day readmission $(P=.004)$ with greater 90-day ED visits that neared statistical significance $(P=.07)$.

$\begin{array}{llll}\text { Quanbeck, } & \text { United } & \text { Seva } & \begin{array}{l}\text { Interventional, } \\ \text { other than RCT }\end{array}\end{array}$

Riippa, 2015 Finland [55]

Patient portal by Interventional,

The Finnish Medi- other than RCT

cal Society,

Duodecim

$\begin{array}{ll}\text { Tsai, } 2019 & \text { United } \\ {[28]} & \text { States }\end{array}$

Epic's personal

health record sys-

Descriptive,

quantitative

tem

MyChart by Epic Interventional, health record sys- other than RCT
876 patients

Significant reduction in hospitalizations and a trend toward fewer $\mathrm{ER}^{\mathrm{e}}$ visits. Increase in HIV screening rates. Change in the rates of HIV risk behaviors (eg, condom use) and receiving other addiction treatments appeared to be nonsignificant.

The effect on the cost of care was ambiguous; costs decreased by an average of $€ 91$ in the unadjusted model, but increased by $€ 48$ in the adjusted model. Due to the controversial result, the unadjusted analysis showed an $89 \%$ probability of cost-effectiveness with no willingness to pay for increased patient activation, whereas in the adjusted sample, the probability of the portal being more cost-effective than care as usual exceeded $50 \%$ at a willingness to pay $€ 700$ per clinically significant increase in the patient activation score. For doctor visits, portal access $(n=80)$ : 3.8 (SD 3.3) and control ( $\mathrm{n}=57)$ : 3.0 (SD 3.1) $(t=1.4$; $P=.18)$. For nurse visits, portal access $(n=80): 3.5$ (SD 2.6) and control (n=57): 4.1 (SD 2.5) $(t=-1.3 ; P=.18)$.

109,200 patients Active users had more outpatient and inpatient visits and fewer ER visits. Patients without a portal account had on average fewer outpatient visits per month (0.31 vs 0.89 , $P<.001)$ and fewer inpatient visits per month (0.007 vs $0.059, P<.001)$, but had more ER visits per month than patients who were active with the portal $(0.047$ vs 0.014 , $P<.001)$. The difference between no-show appointments was not significant.

36,549 patients The number of visits for 12 months was strongly associated with an increased likelihood of MyChart activation and with more frequent MyChart logins. 


\begin{tabular}{|c|c|c|c|c|c|}
\hline $\begin{array}{l}\text { First author, } \\
\text { year }\end{array}$ & Country & $\begin{array}{l}\text { Health information } \\
\text { technology }\end{array}$ & Study design & Sample size & Main findings \\
\hline $\begin{array}{l}\text { Zhong, } 2018 \\
{[42]}\end{array}$ & $\begin{array}{l}\text { United } \\
\text { States }\end{array}$ & $\begin{array}{l}\text { MyUFHealth (also } \\
\text { known as MyChart } \\
\text { by Epic) }\end{array}$ & $\begin{array}{l}\text { Observational, } \\
\text { hypothesis testing }\end{array}$ & $\begin{array}{l}15,659 \text { nonusers } \\
\text { and } 5494 \text { users }\end{array}$ & $\begin{array}{l}\text { At the time of adoption, the quarterly } \mathrm{PCP}^{\mathrm{f}} \text { office visit } \mathrm{RR}^{\mathrm{g}} \\
\text { of users to nonusers was } 1.33(95 \% \mathrm{CI} 1.27-1.39 ; P<.001) \text {. } \\
\text { The RRs were between } 0.94 \text { and } 0.99 \text { up to four quarters } \\
\text { after portal adoption }(P=.75, .10, .13 \text {, and } .09 \text {, respectively), } \\
\text { and it was significantly less than } 1 \text { at the seventh (RR } 0.82 \text {, } \\
95 \% \text { CI } 0.73-0.91 ; P<.001) \text { and eighth (RR } 0.80,95 \% \text { CI } \\
0.70-0.90 ; P<.001) \text { quarters post adoption. The no-show } \\
\text { rate proxies in the user group were significantly lower than } \\
\text { in the nonuser group. RRs were between } 0.60 \text { and } 0.83 \text { for } \\
\text { eight out of } 11 \text { quarters, and for the remaining three quar- } \\
\text { ters, differences were not significant }(P=.65, .29 \text {, and } .44 \text {, } \\
\text { respectively). Differences in cancellation rate proxies were } \\
\text { not significant }(P>.05) \text {. Overall, appointment adherence } \\
\text { improved after portal adoption. }\end{array}$ \\
\hline
\end{tabular}

${ }^{\mathrm{a}} \mathrm{RCT}$ : randomized controlled trial.

${ }^{b}$ ED: emergency department.

${ }^{\mathrm{c}}$ ASA: American Society of Anesthesiology.

${ }^{\mathrm{d}} \mathrm{OR}$ : odds ratio.

${ }^{\mathrm{e}} \mathrm{ER}$ : emergency room.

${ }^{\mathrm{f}} \mathrm{PCP}$ : primary care physician.

${ }^{\mathrm{g}} \mathrm{RR}$ : rate ratio.

Concerning emergency room (ER) visits, a decreasing trend was described [54,60], and active portal users showed more outpatient and inpatient visits and fewer ER visits per month, compared with patients without an account [28]. The number of visits over 6 months for asthmatic patients was lower among users than among nonusers (3 vs 9) [60]. User status was not significantly associated with ED access in the study by Plate et al, and the use of secure messages showed a nonsignificant result [39].

A reduction in hospitalizations was described for asthma [60] and mental health conditions [54]. Different findings were observed in patients with acute myocardial infarction, congestive heart failure, or pneumonia. In these cases, the odds of 30-day readmission for active users was $66 \%$ higher than that for nonusers, while no significant difference was described between nonusers and light users [44]. Considering patients who underwent total hip or knee arthroplasty, there was a significant association between 90-day readmission and sending two or more secure messages [39].

Concerning clinicians' attitudes, the portal seemed to enable a new way of managing stable patients, facilitating clinical and cost-effective use of specialist nurses (improved two-way communication, and more optimal use of outpatient appointments and consultant time). The portal also facilitated a single rationalized pathway for stable patients, enabling access to information and proactive support [48].

Portal use by patients reduced missing appointments [35] and showed an improvement in appointment adherence after portal adoption [42]. However, no significant association between user/nonuser status and no-show appointments was found by one study [28]. The difference in cancellation rate proxies was also not significant between the user and nonuser groups [42].

Finally, concerning other aspects, only one study took into consideration the associated costs with ambiguous results. In this study, costs decreased in the unadjusted model but increased after adjusting for relevant variables [55]. An increase in HIV screening rates was described, but changes in the rates of HIV risk behaviors (eg, condom use) and modification of addiction treatments appeared nonsignificant in mental health patients [54]. Portal use had a positive effect on days of work lost due to asthma patients' issues [60]. Moreover, information services were positively affected by portal use, as it led to a reduced number of requests [35].

\section{Patient Characteristics}

Concerning patients' characteristics, 32 articles presented relevant results that were mainly related to demographic information, such as age, gender, education, and household status (Table 3). 
Table 3. Summary of the findings on patient characteristics.

\begin{tabular}{|c|c|c|c|c|c|}
\hline $\begin{array}{l}\text { First author, } \\
\text { year }\end{array}$ & Country & $\begin{array}{l}\text { Health information } \\
\text { technology }\end{array}$ & Study design & Sample size & Main findings \\
\hline $\begin{array}{l}\text { Abel, } 2018 \\
{[31]}\end{array}$ & $\begin{array}{l}\text { United } \\
\text { States }\end{array}$ & $\begin{array}{l}\text { My HealtheVet } \\
\text { (MHV) and Clinical } \\
\text { Video Telehealth } \\
\text { (CVT) }\end{array}$ & $\begin{array}{l}\text { Descriptive, quantita- } \\
\text { tive }\end{array}$ & $\begin{array}{l}2,171,325 \text { pa- } \\
\text { tients }\end{array}$ & $\begin{array}{l}\text { African American and Latino patients were significant- } \\
\text { ly less likely to engage in use compared with White } \\
\text { patients. Low-income patients with free care were } \\
\text { significantly less likely to be users. Patients with } \\
\text { schizophrenia or schizoaffective disorder were signif- } \\
\text { icantly less likely to be users than those with other } \\
\text { mental health diagnoses (OR }{ }^{\mathrm{a}} 0.50 \text {, CI } 0.47-0.53 \text { and } \\
\text { OR } 0.75 \text {, CI } 0.69-0.80 \text {, respectively). Although rural } \\
\text { patients had } 17 \% \text { lower odds of My HealtheVet adop- } \\
\text { tion compared with urban patients (OR } 0.83,95 \% \text { CI } \\
0.80-0.87 \text { ), they were more likely to engage in Clinical } \\
\text { Video Telehealth and dual use (OR } 2.45,95 \% \text { CI } 1.95- \\
3.09 \text { for Clinical Video Telehealth and OR } 2.11,95 \% \\
\text { CI } 1.81-2.47 \text { for dual use). }\end{array}$ \\
\hline
\end{tabular}

\begin{tabular}{|c|c|c|c|}
\hline $\begin{array}{l}\text { Ancker, } \\
2019[34]\end{array}$ & $\begin{array}{l}\text { United } \\
\text { States }\end{array}$ & $\begin{array}{l}\text { Blood glucose flow } \\
\text { sheet (EpicCare and } \\
\text { Weill Cornell Con- } \\
\text { nect portal) }\end{array}$ & $\begin{array}{l}\text { Observational, hy- } \\
\text { pothesis testing }\end{array}$ \\
\hline
\end{tabular}

Chan, 2018 United

[18] States

$\begin{array}{ll}\text { Fiks, 2015 } & \text { United } \\ {[60]} & \text { States }\end{array}$

Fiks, $2016 \quad$ United [32] States
MyChart (EpicCare, Descriptive, quantita- 17,699 patients Verona, WI) tive

MyAsthma (Clinical RCT $^{\mathrm{b}}$ interface in My-

Chart)

MyAsthma
Descriptive, mixed methods
60 families of children
Pregnant patients: Uploaders were similar to the comparison group in terms of race, ethnicity, age, and socioeconomic status. Uploaders had more clinical encounters and portal logins before initial data upload, earlier establishment of patient portal accounts, and worse baseline blood pressure.

30 chronic disease patients: Uploaders were more likely to be Asian-American and younger, but the groups did not have other significant demographic differences.

Positive associations between portal use and being aged 50-74 years, White, privately insured, Englishspeaking, and living outside San Francisco.

Parents of children with moderate or severe asthma used the portal more frequently $(75 \%$ were frequent users vs $47 \%$ were parents whose child had mild persistent asthma).

Users were more likely to have children aged 6-9 years $(P=.009)$, be White $(P<.001)$, be privately insured $(P<.001)$, have mild persistent or moderate or severe persistent asthma $(P=.002)$, be on an asthma controller medication $(P<.001)$, and be receiving a greater number of asthma medications at baseline on average than nonusers $(P<.001)$. Those with persistent asthma were twice as likely to use the portal versus those with intermittent asthma $(2.37 \%$ vs $1.25 \%$ at hospital practices where these data were available; $P<.001)$. Sustained portal users were more likely than one-time users to be Hispanic $(P=.02)$, have private insurance $(P=.02)$, and be from the Northeast $(P=.001)$. Sustained use parents had higher educational levels $(P=.002)$.

Positively associated with portal adoption in multivariable logistic regression: receipt of a controller medication at baseline (OR 2.0, 95\% CI 1.5-2.7), private insurance (OR 2.0, 95\% CI 1.3-3.1), lower child age (OR 1.4, 95\% CI 1.1-1.9), and greater asthma severity (OR 1.9, 95\% CI 1.2-3.0 for mild and OR 1.9, 95\% CI 1.0-3.5 for moderate or severe persistent vs intermittent). 


\begin{tabular}{lllll}
\hline $\begin{array}{l}\text { First author, } \\
\text { year }\end{array}$ & Country & $\begin{array}{l}\text { Health information } \\
\text { technology }\end{array}$ & Study design & Sample size \\
\hline $\begin{array}{l}\text { Foster, } 2019 \\
{[43]}\end{array}$ & $\begin{array}{l}\text { United } \\
\text { States }\end{array}$ & Epic MyChart & $\begin{array}{l}\text { Observational, hy- } \\
\text { pothesis testing }\end{array}$ & 208,635 tests \\
& & 20 & &
\end{tabular}

Main findings

$\begin{array}{ll}\text { Gordon, } & \text { United } \\ 2016[20] & \text { States }\end{array}$

\begin{tabular}{|c|c|c|c|}
\hline $\begin{array}{l}\text { Gossec, } \\
2017 \text { [59] }\end{array}$ & France & Sanoia & $\mathrm{RCT}$ \\
\hline $\begin{array}{l}\text { Griffin, } 2016 \\
\text { [44] }\end{array}$ & $\begin{array}{l}\text { United } \\
\text { States }\end{array}$ & My UNC Chart & $\begin{array}{l}\text { Observational, hy- } \\
\text { pothesis testing }\end{array}$ \\
\hline $\begin{array}{l}\text { Huang, } 2019 \\
{[45]}\end{array}$ & $\begin{array}{l}\text { United } \\
\text { States }\end{array}$ & $\begin{array}{l}\text { myPennMedicine } \\
\text { (branded version of } \\
\text { Epic MyChart) }\end{array}$ & $\begin{array}{l}\text { Observational, hy- } \\
\text { pothesis testing }\end{array}$ \\
\hline
\end{tabular}

Jhamb, 2015 United [46] States
Free patient portal Observational, hy- 1098 patients tethered to an ambu- pothesis testing latory $\mathrm{EHR}^{\mathrm{c}}$
Kaiser Permanente Observational, hyNorthern California pothesis testing/depatient portal scriptive, quantitative

$231,082 \mathrm{pa}-$ tients/4980 patients

320 patients

2975 patients

10,000 patients Epic MyChart)
Females $(5546 / 13,149,42.18 \%)$ were significantly more likely to activate the portal than males $(3897 / 12,212,31.91 \% ; P<.001)$. Activation rates were highest for Asian $(262 / 451,58.1 \%)$ and White individuals $(8155 / 20,637,39.52 \%)$ and lower for African American/Black (491/2254, 21.78\%; $P<.001$ compared with White), Hispanic/Latino (333/1257, 26.49\%; $P<.001$ compared with White), and other individuals (241/762, 31.6\%; $P<.001$ compared with White). The activation rate for patients aged $18-70$ years was $41.61 \%(7593 / 18,246)$. The overall pattern of radiologic image viewing with respect to age and gender showed similar trends to those described for laboratory testing.

Older seniors (aged 70-74 and 75-79 years) were significantly less likely than those aged 65-69 years to have registered, and to have used the patient portal to send a secure message, view laboratory test results online, or order prescription refills at least once by the end of the year. Slightly over $70 \%$ had been diagnosed with a chronic cardiovascular condition, and $90 \%$ reported taking at least one prescription medication for a chronic condition.

In multivariate analyses, the only factor related to connecting more than twice to the platform was being a member of a patient association (OR 1.44, 95\% CI $1.17-1.77 ; P<.001)$. In the groups with high and low numbers of connections, the percentages of patient association members were $24.7 \%$ and $6.5 \%$, respectively.

Active users had a higher proportion of Caucasian patients, higher Charlson Comorbidity scores, and a higher proportion of patients admitted to an academic medical center than light users.

Users were more likely to be younger (63.46 years [users] vs 66.08 years [nonusers]; $P<.001)$ and have higher income (US $\$ 74,172$ [users] vs US $\$ 62,940$ [nonusers]; $P<.001$ ) than nonusers. The percentage of White race was substantially higher among users (72.77\% [4317/5932] [users] vs 52.58\% [2139/4068] [nonusers]; $P<.001)$. For users, the percentage of payments by commercial insurance was higher (60.99\% [3618/5932] [users] vs 40.12\% [1632/4068] [nonusers]; $P<.001)$ and the percentage of payments by Medicare or Medicaid was lower (Medicare: $34.91 \%$ [2071/5932] [users] vs $48.72 \%$ [1982/4068] [nonusers]; $P<.001$; and Medicaid: $3.49 \%$ [207/5932] [users] vs $10.08 \%$ [410/4068] [nonusers]; $P<.001$ ).

The difference in sex between users and nonusers was not statistically significant. No significant difference was found in any provider-level characteristic between the two groups.

Users were younger and more likely to be non-Black, be married, have private insurance, and have higher neighborhood median household income. Users were less likely to have diabetes, coronary artery disease, or congestive heart failure, but were more likely to have had a kidney transplant. Older age, Black race, unmarried status, Medicaid or Medicare insurance (vs private), and lower neighborhood median household income were associated with not using the portal. 


\begin{tabular}{|c|c|c|c|c|c|}
\hline $\begin{array}{l}\text { First author, } \\
\text { year }\end{array}$ & Country & $\begin{array}{l}\text { Health information } \\
\text { technology }\end{array}$ & Study design & Sample size & Main findings \\
\hline $\begin{array}{l}\text { Kipping, } \\
2016 \text { [35] }\end{array}$ & Canada & $\begin{array}{l}\text { Ontario Shores } \\
\text { HealthCheck Patient } \\
\text { Portal }\end{array}$ & $\begin{array}{l}\text { Observational, hy- } \\
\text { pothesis testing }\end{array}$ & 91 patients & $\begin{array}{l}\text { A similar proportion of patients }(1756 / 3158,55.6 \%) \\
\text { and portal users }(266 / 432,61.6 \%) \text { were female. Age } \\
\text { distribution was relatively similar. The majority of } \\
\text { users were between } 25 \text { and } 34 \text { years. }\end{array}$ \\
\hline
\end{tabular}

Krist, 2014 United AllscriptsTouch- Descriptive, mixed 112,893 patient

[33] States

Laranjo, Australia

2017 [22]

Lau, 2014 Canada BCDiabetes.ca

[36]

Manard, United

2016 [37] States

Mishra, United

$2019[23] \quad$ States
Online patient portal Observational, hypothesis testing
1571 patients
109,619 participants

Observational, hypothesis testing
1957 patients

(20)

Older patients were more likely to create a PHR ${ }^{\mathrm{d}}$ account as they had chronic conditions.

Geographic analysis revealed higher proportions of PHR adoption in urban centers when compared with rural noncoastal districts.

Users tended to be younger (mean difference of 4.28 years; $P=.06$ ), have lower baseline $\mathrm{HbA}_{1 \mathrm{c}}$ (mean difference of $0.89 \% ; P<.01$ ), and have higher baseline weight (mean difference of $7.53 \mathrm{~kg} ; P=.06$ ) than nonusers. There was no difference in gender or total follow-up time. Follow-up $\mathrm{HbA}_{1 \mathrm{c}}$ levels tended to be lower in users than nonusers (mean difference of $0.75 \% ; P<.01)$, and users were significantly more likely to have $\mathrm{HbA}_{1 \mathrm{c}}$ of $7 \%$ at their last follow-up visit $(P=.01)$. No significant differences in $\mathrm{LDL}^{\mathrm{e}}$ and $\mathrm{SBP}^{\mathrm{f}}$ were observed between users and nonusers at initial visits and follow-up visits.

Users were significantly younger $(P<.001)$, more often White $(P<.001)$, and more often married $(P<.001)$ than nonusers. Users were significantly from upper-middle to the highest socioeconomic status compared with nonusers $(P<.001)$. Portal use was more common among $\mathrm{FM}^{\mathrm{g}}$ patients than $\mathrm{GIM}^{\mathrm{h}}$ patients $(P<.001)$, and users were more often high health care utilizers $(P<.02)$. Portal use was less common among current smokers $(P<.001)$. Users were more likely to have depression $(P<.01)$ and lower comorbidity scores $(P<.001)$.

Overall, $90 \%(\mathrm{n}=784)$ were above 30 years, with $8 \%$ between 18 and 29 years; $40 \%$ were above 60 years; and $50 \%$ were between 30 and 59 years. One participant stated accessing the portal for a minor and another as a family surrogate. Moreover, $92 \%(n=797)$ had a college degree or greater, $24 \%(n=205)$ had a graduate degree, and $1 \%(n=12)$ had less than 12 th grade education. Individuals in the 18-29 and >60 years groups were more likely to find the notes helpful. Greater note comprehension was correlated with greater education. Noncollege participants were more likely to access notes "many times" than college participants $(P=.02)$.

$\begin{array}{ll}\text { North, 2014 } & \text { United } \\ \text { [38] } & \text { States } \\ & \\ \text { Plate, 2019 } & \text { United } \\ \text { [39] } & \text { States }\end{array}$

Mayo Clinic Health Observational, hySystem pothesis testing

2357 primary care patients

MyChart; Epic Sys- Observational, hy- 6426 patients tems Corporation pothesis testing
The majority of patients sending messages were female, were White, lived locally, and were employed by the Mayo Clinic.

Overall, 4623 people registered on MyChart logged into the patient portal at least once within 1 year from surgery, and 1803 (28\%) patients were not registered users. Active users were significantly more likely to be young, have a healthy ASA A $^{\mathrm{i}}$ score (ASA 1 or 2), be Caucasian, be married, be employed, be privately insured, and be discharged to home. Patients not using MyChart had a higher ASA score (ASA 3 or 4) and were more likely to be African American, unmarried, and unemployed. Patients without MyChart were more likely to have Medicare or Medicaid insurance and be discharged to a skilled nursing facility. 


\begin{tabular}{|c|c|c|c|c|c|}
\hline $\begin{array}{l}\text { First author, } \\
\text { year }\end{array}$ & Country & $\begin{array}{l}\text { Health information } \\
\text { technology }\end{array}$ & Study design & Sample size & Main findings \\
\hline $\begin{array}{l}\text { Portz, } 2019 \\
\text { [52] }\end{array}$ & $\begin{array}{l}\text { United } \\
\text { States }\end{array}$ & $\begin{array}{l}\text { My Health Manager } \\
\text { (Kaiser Permanente } \\
\text { Colorado patient } \\
\text { portal) }\end{array}$ & $\begin{array}{l}\text { Qualitative descrip- } \\
\text { tive study }\end{array}$ & 24 patients & $\begin{array}{l}\text { The mean age was } 78 \text { years. Patients were primarily } \\
\text { White }(12,80 \%) \text { and women }(12,80 \%) \text {. Education: } \\
\text { high school graduate, } 1(7 \%) \text {; some college graduate, } \\
7(47 \%) \text {; and college graduate, } 7(47 \%) \text {. Income: <US } \\
\$ 30,000,2(13 \%) ; \text { US } \$ 30,000-49,999,7(47 \%) \text {; US } \\
\$ 50,000-74,999,2(13 \%) ;>\text { US } \$ 75,000,2(13 \%) \text {; } \\
\text { chose not to answer, } 2(13 \%) \text {. }\end{array}$ \\
\hline
\end{tabular}

\begin{tabular}{|c|c|c|c|}
\hline $\begin{array}{l}\text { Powell, } 2018 \\
\text { [40] }\end{array}$ & $\begin{array}{l}\text { United } \\
\text { States }\end{array}$ & $\begin{array}{l}\text { FollowMyHealth } \\
\text { portal }\end{array}$ & $\begin{array}{l}\text { Observational, hy- } \\
\text { pothesis testing }\end{array}$ \\
\hline
\end{tabular}

[40] States portal

No significant relationship between the number of logins and any of the demographic variables; however, when those with zero logins were removed from the model, age, distance separating the patient from his or her provider, and having a diagnosis of heart failure were all significant predictors of portal use $(P<.05)$.

Price-Hay- United wood, 2017 States [25]

MyOchsner patient portals (Epic Sys-

Descriptive, quantita- 247 patients tive

Portal users had higher levels of education, lower rates of inadequate health literacy, and higher rates of using the internet and having an interest in websites or smartphone apps for tracking health. The odds of portal use increased with total eHEALS scores (health literacy scale) and decreased among Black patients.

nology, smartphone mobile apps

Riippa, 2014 Finland [56]

No specific portal

Interventional, other 876 patients than RCT

Patients with a severe diagnosis during the intervention showed the greatest positive change in patient activation (mean change 5.4, SD 8.4). Patients diagnosed 12 years ago (mean change 2.3, SD 15.7) and patients with no severe diagnoses (mean change 1.6, SD 13.1) showed a positive change in patient activation.

Ronda, 2014 Netherlands [26]

Digitaal Logboek

Descriptive, quantita- 1390 patients tive

Multivariable analysis showed that increasing age and smoking were associated with not using the portal. A higher educational level, treatment by an internist, using insulin, polypharmacy, better diabetes knowledge, and more hyperglycemic episodes were less likely to be associated with not using the portal

Smith, 2015 United EpicCare

[27] States

Descriptive, quantita- 534 patients tive

Significant predictors of registering were as follows: gender (male $65.3 \%$ vs female $55.1 \%$ ), race (White $71.7 \%$ vs African American $27.7 \%$ vs "other" races $41.7 \%$ ), education (more educated people were more likely to register), number of chronic conditions (70.9\% with zero conditions, $63.2 \%$ with one condition, and $50.0 \%$ with two or more conditions), health literacy (adequate $72.7 \%$ vs marginal $46.4 \%$ vs limited health literacy $21.7 \%$ ).

Sun, $2019 \quad$ United

Epic's personal Observational, hy-

38,399 patients health record system pothesis testing

Almost one-third of patients $(\mathrm{n}=12,615 ; 32.9 \%, 95 \%$ CI $32.38 \%-33.32 \%$ ) had used the portal for a mean of 2.5 (SD 1.9) years prior to the study period. Portal use was higher on weekdays $(P<.001)$. An increase in portal use was observed in response to email reminders. A nonlinear relationship between age and portal use was observed and depended on several other predictors $(P<.05)$. Patients living in more rural areas with low income were at lower odds to use the portal $(P=.02)$, and this finding also applied to non - Whites with low income $(P<.001)$. More chronic conditions and a higher initial $\mathrm{HbA}_{1 \mathrm{c}}$ value were associated with portal use $(P=.01)$.

Tsai, 2019 United

[28] States

Epic's personal

Descriptive, quantita-

109,200 patients health record system tive

Active portal users were on average older (49.45 vs 46.22 years) and frequently female $(62.59 \%$ vs $54.91 \%)$. Both the differences in mean age $(P=.008)$ and gender $(P=.04)$ were significant. There was a bimodal peak in terms of active users, with active users more likely to be in their 30s and 60s. The difference among age groups was significant $(P<.001)$. Differences in racial composition, insurance, and language were not significant. 


\begin{tabular}{|c|c|c|c|c|c|}
\hline $\begin{array}{l}\text { First author, } \\
\text { year }\end{array}$ & Country & $\begin{array}{l}\text { Health information } \\
\text { technology }\end{array}$ & Study design & Sample size & Main findings \\
\hline $\begin{array}{l}\text { Van der } \\
\text { Vaart, } 2014 \\
{[57]}\end{array}$ & Netherlands & $\begin{array}{l}\text { Medisch Spectrum } \\
\text { Twente }\end{array}$ & $\begin{array}{l}\text { Interventional, other } \\
\text { than RCT }\end{array}$ & 360 patients & $\begin{array}{l}\text { Univariate analyses showed that age, marital status, } \\
\text { education level, employment, health literacy, and in- } \\
\text { ternet-related characteristics were significantly related } \\
\text { to portal use. Nonusers were more often older, single, } \\
\text { lower educated, and unemployed. Respondents with } \\
\text { higher health literacy were more inclined to login on } \\
\text { the portal, and respondents who used the internet more } \\
\text { often had more years of experience and perceived their } \\
\text { own skills as better. }\end{array}$ \\
\hline
\end{tabular}

$\begin{array}{llll}\begin{array}{l}\text { Wade-Vu- } \\ \text { turo, 2013 } \\ \text { [8] }\end{array} & \begin{array}{l}\text { United } \\ \text { States }\end{array} & \begin{array}{l}\text { MyHealthAtVander- } \\ \text { bilt patient portal }\end{array} & \begin{array}{l}\text { Descriptive, quantita- } \\ \text { tive }\end{array} \\ & & \\ \text { Wallace, } & \text { United } & \begin{array}{l}\text { MyChart by Epic } \\ \text { health record system }\end{array} & \begin{array}{l}\text { Interventional, other } \\ \text { than RCT }\end{array}\end{array}$

Participant age, gender, race, income, and education level were not associated with using $\mathrm{SM}^{\mathrm{j}}$ to send a message to a provider for any reason or using SM to schedule an appointment.

Men, non-White patients, and Hispanic patients were significantly less likely to login once, 2 to 23 times, or 24 times than women, White patients, or non-Hispanic patients. Patients with public insurance were less likely to login than those with private insurance across all MyChart usage categories. Patients with income levels $100 \%$ of the $\mathrm{FPL}^{\mathrm{k}}$ were more likely to login one time than those below the FPL level.

$\begin{array}{llll}\text { Wedd, 2019 } & \begin{array}{l}\text { United } \\ \text { [30] }\end{array} & \begin{array}{l}\text { Unspecified patient } \\ \text { States }\end{array} & \begin{array}{l}\text { Descriptive, quantita- } \\ \text { portal }\end{array}\end{array}$

MyUFHealth (also Observational, hyknown as MyChart pothesis testing by Epic)
15,659 nonusers and 5494 users
Black patients were less likely to use the portal vs White patients among both kidney (Black 57\% vs White $74 \%$ ) and liver (Black $28 \%$ vs White $55 \%$ ) transplant recipients. In adjusted multivariable analyses, kidney transplant recipients were more likely to use the portal if they had higher education. Among liver recipients, patients who were White and had higher education were more likely to use the portal.

The user group comprised $53.1 \%$ patients with more than four chronic problems (vs $40.2 \%$ of the matched nonuser group), and had more patients bearing 10 or more chronic problems (18.2\% vs $12.2 \%)$. Individuals enrolled in the patient portal were mostly middle aged (31-64 years) and female. Married patients were more likely to adopt the portal. Medicare and Medicaid patients, and Black or African American patients were less likely to be adopters. Portal adoption was also associated with the baseline number of active medical problems $(P<.05)$.

\footnotetext{
${ }^{\mathrm{a} O R}$ : odds ratio.

${ }^{\mathrm{b}} \mathrm{RCT}$ : randomized controlled trial.

${ }^{c}$ EHR: electronic health record.

${ }^{\mathrm{d}}$ PHR: personal health record.

${ }^{\mathrm{e}} \mathrm{LDL}$ : low-density lipoprotein.

${ }^{\mathrm{f}} \mathrm{SBP}$ : systolic blood pressure.

${ }^{\mathrm{g}} \mathrm{FM}$ : family medicine.

${ }^{\mathrm{h}}$ GIM: general internal medicine.

${ }^{\mathrm{i}}$ ASA: American Society of Anesthesiology.

${ }^{\mathrm{j}} \mathrm{SM}$ : secure messaging.

${ }^{k}$ FPL: federal poverty level.
}

In terms of age, results were not homogeneous. Higher use in older patients (aged >50 years) was described in four studies $[18,20,21,33]$. In a middle age and elderly cohort, the mean age of users was significantly lower [45]. On the other hand, younger patients were also the major users in disease/specialty-specific cohorts $[32,35,46]$.
A total of 19 studies mentioned the origin and ethnicity of users [8,18,25,27,30-32,34,37-39,42-46,52,58]. White patients were usually the most likely to use the portals described in the different studies [18,27,30-32,37,38,43,45,52]. Two studies found no significant association between ethnicity and portal use $[8,28]$. 
Most of the articles found a positive association between female gender and portal use [28,35,38,42,43,58]. Only one study, conversely, found male gender to be a predictor of registering [27]. No statistically significant association between sex and user/nonuser status was found in two articles [36,45].

In a cohort of patients with mental disorders, having schizophrenia or schizoaffective disorders was negatively associated with portal use [31]. Instead, depression was positively associated [37]. Moderate or severe asthma was more linked to portal use [32,60]. Moreover, having a diagnosis of diabetes, hypertension, heart failure, or cardiovascular disease was a significant predictor of portal use [20,40], with one exception [46]. On the other hand, there were contrasting results concerning the association between the number of comorbidities and portal use $[27,37,41,42,44]$.

People living in rural areas were less likely to use patient portals than urban citizens in three studies [22,31,41], while higher education levels were often related to broader use of portals [23,25-27,30,32,52,57]. Only one study showed no significant association [8]. Higher income was also generally associated with portal use [31,37,45,46,58]. Only one study found no association between income and the use of secure messages [8].

Studies conducted in the United States showed that having a private insurance was positively associated with portal use $[18,32,39,42,45,46,58]$, with only one study reporting the absence of this association [28].

Other patient characteristics positively associated with portal use were being a member of a patient association [59] and being admitted to an academic medical center [44].

\section{Attitudes and Satisfaction}

Patient attitudes were evaluated in terms of perceived barriers and facilitators toward portal use. The overall satisfaction was also assessed, and it refers to the extent to which the patient is content about health care. Thirty articles addressed these topics (Multimedia Appendix 4).

Nine articles clearly addressed the barriers to portal use. Some of the main issues were related to perceived or preconceived security concerns $[8,48]$, limited knowledge [26,51], satisfaction with current care [51], paying for the service [54], disinterest in managing one's own disease [26,57], personal/time constraints and not thinking about accessing the portal [57,61], doubts about the reliability of the patient portal to facilitate a timely and productive message exchange with providers [8], and prior negative experiences with secure messaging [8]. Other barriers were related to population characteristics, such as being a clinician older than 55 years or younger than 35 years and being male [33], and variation in provider availability for online appointment scheduling and response times to medical messages [25]. Limited computer and internet access [20,25,26,51,57], knowledge of technology [25,26,57], security concerns $[25,48]$, and data integration [48] were also negative predictors of portal use.

On the other hand, nine articles specified the elements that facilitated portal use, including improved communication with specialists $[22,48,60]$; availability of information that led to an increased awareness of the health status [19,22,32,51,60] and tracking of disease control [32]; time-saving, convenient, and easy to use elements [19]; accuracy, timeliness, usefulness, and convenience of the functionalities included in the portal [22,50]; availability of surrogates (ie, daughter or family member) to act as intermediaries [51]; active involvement of the practice/staff in the promotion of the portal (ie, team approach strategy to engage staff in notifying patients) [33]; and active training of the patient for portal use [61]. Concerning satisfaction, patients were generally satisfied with the portals [8,17,21,29,49,50,59-61].

\section{Discussion}

Due to the considerable amount of literature published on the topic of patient portals, the aim of this review was to provide evidence and to gather information systematically. Similar to the review published in 2013 by Goldzweig et al [4], the outcomes were grouped into four aspects, namely, health outcomes and adherence, health care efficiency, patient characteristics, and attitudes and satisfaction, and showed nonunique results in terms of benefits brought by patient portals concerning patient experience and health. The functionalities available in the portals described by Goldzweig et al and our review were likewise the same.

Positive results were described relating to the enhancement of preventive behaviors [45], changes in chronic condition control with higher control of diabetes parameters [34,36], and asthma flares [60]. However, conflicting results were described concerning blood pressure control [34,37], mental health conditions [35,54,55], and medication adherence [32,57]. A possible explanation of these results is that these particular studies involved patients (often with a low sample size) who utilized portals for a short period of time, preventing them from having a possible consistent outcome. Similarly, concerning health outcomes, Goldzweig et al found generally positive results, which documented improvement in patients' disease control and maintenance [4], even though many of the included studies in our review did not find a significant difference between portal users and nonusers. Adherence to therapy was always improved [4] similar to that in this review.

The number of clinical and ED visits [28,32,39,54,60] and hospital readmissions $[39,44,54,60]$ did not always decline in patients using portals. The number of missed appointments decreased $[35,42]$, but this finding was not always significant $[28,42]$. The nondeclining trends of hospitalizations and outpatient visits as a consequence of portal use are concordant in the two studies, although different findings were described. Indeed, different from our review, in which we found more often a decrease in the utilization of in-person services, the review by Goldzweig et al reported that most of the studies found an increased number of outpatient visits and hospitalizations. As patient portals are normally designed to reduce inappropriate health care utilization, this might be partially explained by the fact that provider and patient adaptations to the patient portals have evolved over time.

The studies differed also in terms of the population included, with conflicting results in portal adoption and age, gender, 
ethnicity, kind of disease, and number of comorbidities. Generally, having a higher income $[31,37,45,46,58]$ and having a private insurance were associated with increased portal use $[18,32,39,42,45,46,58]$.

The main barriers faced in using the portals were (1) user-related issues, such as time constraints [57,61], disinterest in managing the disease [26,57], and limited digital knowledge [26,51]; (2) clinician-related issues, such as age [33] and attitude toward the portal [33]; and (3) technology-related issues, such as limited internet access $[25,26,51,57]$ or ability to use technology $[25,26,57]$ and security concerns [25,48]. Privacy and security concerns, and ability to use technological appliances and systems were the most important barriers to utilization described in the studies retrieved by Goldzweig et al [4]. Indeed, other recent reviews on patient attitudes highlighted that privacy and security problems are the main barriers to the use of patient portals. These barriers are as evident in elderly patients (in whom there is also a limitation of portal use related to age) as in younger patients $[62,63]$. Moreover, technical problems due to patient capacity and difficulties in using the portal also represent important barriers. Thus, correct and adequate information on safety issues and education on the technical use of the portal represent the best facilitators. Furthermore, engaging patients and making them realize that the portal represents a useful tool to support the management of their pathology (especially for chronic diseases) without replacing the doctor-patient relationship are important to encourage the use of digital portals $[13,62,64]$. In addition, technical improvements in the usability of portals could increase patient enrollment.

Security problems are complex issues that must be considered in any part of medical care. The use of information technologies in health care that can be accessed by multiple types of users (physician, patient, caregiver, and hospital administrative staff) represents the basis of the discussion about computer security [65]. Indeed, uncertainties about security of clinical data might hinder adoption of systems by both hospitals and patients [48]. Patients expressed concern about their privacy and the privacy of their family members, and asked for further information about confidentiality, as vulnerable data might be accessed by external providers, such as insurance providers, who are the main actors of health care access in many countries [47].

The facilitators retrieved were the prompt availability of health information that caused an increase in the awareness of the health status [19,22,32,51,60], improved communication with health care professionals [22,48,60], and the accuracy, timeliness, usefulness, and convenience of the functionalities included in the portal $[22,50]$. In this latter argument, some functionalities of the portal were found to be more useful than others, including laboratory tests and imaging [23,24,29,43,52], medical notes [23,26], messaging with providers [52], medication refill [52], and current medication list [29]. Generally and as observed by Goldzweig et al [4], patients declared being satisfied with the use of digital tools [8,17,21,29,49,50,59-61].

Despite the considerable number of studies included, the high heterogeneity in terms of outcomes and described portal functionalities did not allow us to perform meta-analyses and to draw generalizable and strong conclusions concerning the utility of the unique features of the portals.

Technological and digital innovations in health care could contribute to achieving the health system goals of equity, efficiency, accessibility, quality, and sustainability, if they are purposefully designed and cost-effectively implemented. When designing a new patient portal or a new functionality, developers and providers should always consider to which health care need they are trying to respond and if other nondigital interventions may be more effective or as effective at a lower cost.

Moreover, the adoption of a new technology is a complex process, depending on the content and the context in which it is introduced. As an example, our review demonstrated that it is feasible to achieve better medication adherence in chronic disease patients through portal use, and highlighted the main facilitators (eg, prompt availability of reliable information and accessibility of communication with disease specialists) and barriers (eg, security and usability concerns, and limited digital knowledge) to portal use. Keeping in mind these contextual factors could ease the difficult task of identifying the best digital tool for a specific population.

Before designing or implementing a new tool, it can be useful to analyze the ideal conditions needed for the adaptation, transfer, absorption, up-scaling, and enhancement of digital technologies. By ideal conditions, we basically mean a situation where the new technology has demonstrated effectiveness in trials or pilots, the provider is committed to guarantee continuous improvement in user accessibility and usability, and the main barriers in the target population are given due consideration. In the absence of these conditions, satisfactory results may be difficult to reach or may take many years to be observed.

The benefits of digitalization cannot be taken for granted and the use of technology does not always lead to an improvement in patient care and health system performance; thus, there is a need for evidence, which is, to date, scarce. The identification of a set of main features with proven efficacy for a patient portal is a useful starting point for the development and implementation of patient-oriented portals. Further studies should be conducted in different aspects of digitalization in health care. None of the studies retrieved analyzed the cost-effectiveness of portal use. Similarly, none of the studies compared the portals to each other, which could be interesting to point out the best practices and features.

Even though a patient portal is not a new concept, its real utilization and implementation are still far from optimal, and it seem to be still considered a "future technology." It is important to adapt the portal functions to the needs and capacities of patients, in order to facilitate the use of this technology and improve its dissemination. In particular, overcoming ethnic and literacy barriers to portal use represents a fundamental goal to create more equitable, effective, and safe health care systems. 


\section{Authors' Contributions}

All authors contributed to the study conception and design. Material preparation and data collection were performed by EC, LV, AMP, AG, and AB. EC and LV screened the articles, with any disagreement finally discussed and resolved with AMP. The first draft of the manuscript was written by EC, LV, AMP, AG, and AB. WR and SB commented on the latest version of the manuscript. WR and SB supervised the study. All authors read and approved the final manuscript.

\section{Conflicts of Interest}

None declared.

\section{Multimedia Appendix 1}

Search string.

[DOCX File, 12 KB-Multimedia Appendix 1]

\section{Multimedia Appendix 2}

Functions and details of patient portals.

[DOCX File , 25 KB-Multimedia Appendix 2]

\section{Multimedia Appendix 3}

Qualitative descriptions of the portals and/or features studied in the included articles.

[DOCX File, $30 \mathrm{~KB}-$ Multimedia Appendix 3]

\section{Multimedia Appendix 4}

Summary of the findings on patient attitudes and satisfaction. [DOCX File, 27 KB-Multimedia Appendix 4]

\section{References}

1. Pagliari C, Detmer D, Singleton P. Potential of electronic personal health records. BMJ 2007 Aug 18;335(7615):330-333 [FREE Full text] [doi: 10.1136/bmj.39279.482963.AD] [Medline: 17703042]

2. Global Strategy on Digital Health 2020-2024. World Health Organization. 2019. URL: https://extranet.who.int/dataform/ upload/surveys/183439/files/Draft\%20Global\%20Strategy\%20on\%20Digital\%20Health.pdf [accessed 2020-11-07]

3. Dendere R, Slade C, Burton-Jones A, Sullivan C, Staib A, Janda M. Patient Portals Facilitating Engagement With Inpatient Electronic Medical Records: A Systematic Review. J Med Internet Res 2019 Apr 11;21(4):e12779 [FREE Full text] [doi: 10.2196/12779] [Medline: 30973347]

4. Goldzweig CL, Orshansky G, Paige NM, Towfigh AA, Haggstrom DA, Miake-Lye I, et al. Electronic patient portals: evidence on health outcomes, satisfaction, efficiency, and attitudes: a systematic review. Ann Intern Med 2013 Nov 19;159(10):677-687. [doi: 10.7326/0003-4819-159-10-201311190-00006] [Medline: 24247673]

5. Otte-Trojel T, de Bont A, Rundall TG, van de Klundert J. How outcomes are achieved through patient portals: a realist review. J Am Med Inform Assoc 2014 Jul;21(4):751-757 [FREE Full text] [doi: 10.1136/amiajnl-2013-002501] [Medline: 24503882]

6. Wong J, Steitz B, Rosenbloom S. Characterizing the impact of health literacy, computer ability, patient demographics, and portal usage on patient satisfaction with a patient portal. JAMIA Open 2019 Dec;2(4):456-464 [FREE Full text] [doi: 10.1093/jamiaopen/ooz058] [Medline: 32025642]

7. D'Costa SN, Kuhn IL, Fritz Z. A systematic review of patient access to medical records in the acute setting: practicalities, perspectives and ethical consequences. BMC Med Ethics 2020 Mar 02;21(1):18 [FREE Full text] [doi:

10.1186/s12910-020-0459-6] [Medline: 32122332]

8. Wade-Vuturo AE, Mayberry LS, Osborn CY. Secure messaging and diabetes management: experiences and perspectives of patient portal users. J Am Med Inform Assoc 2013 May 01;20(3):519-525 [FREE Full text] [doi: 10.1136/amiajnl-2012-001253] [Medline: 23242764]

9. Green BB, Cook AJ, Ralston JD, Fishman PA, Catz SL, Carlson J, et al. Effectiveness of home blood pressure monitoring, Web communication, and pharmacist care on hypertension control: a randomized controlled trial. JAMA 2008 Jun 25;299(24):2857-2867 [FREE Full text] [doi: 10.1001/jama.299.24.2857] [Medline: 18577730]

10. Simon GE, Ralston JD, Savarino J, Pabiniak C, Wentzel C, Operskalski BH. Randomized trial of depression follow-up care by online messaging. J Gen Intern Med 2011 Jul;26(7):698-704 [FREE Full text] [doi: 10.1007/s11606-011-1679-8] [Medline: 21384219]

11. Tang PC, Overhage JM, Chan AS, Brown NL, Aghighi B, Entwistle MP, et al. Online disease management of diabetes: engaging and motivating patients online with enhanced resources-diabetes (EMPOWER-D), a randomized controlled trial. 
J Am Med Inform Assoc 2013 May 01;20(3):526-534 [FREE Full text] [doi: 10.1136/amiajnl-2012-001263] [Medline: 23171659]

12. Cho AH, Arar NH, Edelman DE, Hartwell PH, Oddone EZ, Yancy WS. Do diabetic veterans use the Internet? Self-reported usage, skills, and interest in using My HealtheVet Web portal. Telemed J E Health 2010 Jun;16(5):595-602. [doi: 10.1089/tmj.2009.0164] [Medline: 20575727]

13. Amante DJ, Hogan TP, Pagoto SL, English TM. A systematic review of electronic portal usage among patients with diabetes. Diabetes Technol Ther 2014 Nov;16(11):784-793. [doi: 10.1089/dia.2014.0078] [Medline: 24999599]

14. Han H, Gleason K, Sun C, Miller H, Kang S, Chow S, et al. Using Patient Portals to Improve Patient Outcomes: Systematic Review. JMIR Hum Factors 2019 Dec 19;6(4):e15038 [FREE Full text] [doi: 10.2196/15038] [Medline: 31855187]

15. Moher D, Liberati A, Tetzlaff J, Altman DG, PRISMA Group. Preferred reporting items for systematic reviews and meta-analyses: the PRISMA statement. PLoS Med 2009 Jul 21;6(7):e1000097 [FREE Full text] [doi:

10.1371/journal.pmed.1000097] [Medline: 19621072]

16. Abd-Alrazaq A, Bewick BM, Farragher T, Gardner P. Factors Affecting Patients' Use of Electronic Personal Health Records in England: Cross-Sectional Study. J Med Internet Res 2019 Jul 31;21(7):e12373 [FREE Full text] [doi: 10.2196/12373] [Medline: 31368442$]$

17. Byczkowski TL, Munafo JK, Britto MT. Family perceptions of the usability and value of chronic disease web-based patient portals. Health Informatics J 2014 Jun;20(2):151-162 [FREE Full text] [doi: 10.1177/1460458213489054] [Medline: 24056751]

18. Chan B, Lyles C, Kaplan C, Lam R, Karliner L. A Comparison of Electronic Patient-Portal Use Among Patients with Resident and Attending Primary Care Providers. J Gen Intern Med 2018 Dec;33(12):2085-2091 [FREE Full text] [doi: 10.1007/s11606-018-4637-x] [Medline: $\underline{\text { 30187376] }}$

19. de Jong JM, Ogink PA, van Bunningen CG, Driessen RJ, Engelen LJ, Heeren B, et al. A Cloud-Based Virtual Outpatient Clinic for Patient-Centered Care: Proof-of-Concept Study. J Med Internet Res 2018 Sep 24;20(9):e10135 [FREE Full text] [doi: 10.2196/10135] [Medline: 30249584]

20. Gordon NP, Hornbrook MC. Differences in Access to and Preferences for Using Patient Portals and Other eHealth Technologies Based on Race, Ethnicity, and Age: A Database and Survey Study of Seniors in a Large Health Plan. J Med Internet Res 2016 Mar 04;18(3):e50 [FREE Full text] [doi: 10.2196/jmir.5105] [Medline: 26944212]

21. Jackson SL, DesRoches CM, Frosch DL, Peacock S, Oster NV, Elmore JG. Will use of patient portals help to educate and communicate with patients with diabetes? Patient Educ Couns 2018 May;101(5):956-959. [doi: 10.1016/j.pec.2017.11.004] [Medline: 29153758]

22. Laranjo L, Rodolfo I, Pereira AM, de Sá AB. Characteristics of Innovators Adopting a National Personal Health Record in Portugal: Cross-Sectional Study. JMIR Med Inform 2017 Oct 11;5(4):e37 [FREE Full text] [doi: 10.2196/medinform.7887] [Medline: 29021125]

23. Mishra VK, Hoyt RE, Wolver SE, Yoshihashi A, Banas C. Qualitative and Quantitative Analysis of Patients' Perceptions of the Patient Portal Experience with OpenNotes. Appl Clin Inform 2019 Jan;10(1):10-18 [FREE Full text] [doi: 10.1055/s-0038-1676588] [Medline: 30602196]

24. Moll J, Rexhepi H, Cajander Å, Grünloh C, Huvila I, Hägglund M, et al. Patients' Experiences of Accessing Their Electronic Health Records: National Patient Survey in Sweden. J Med Internet Res 2018 Nov 01;20(11):e278 [FREE Full text] [doi: 10.2196/jmir.9492] [Medline: 30389647]

25. Price-Haywood EG, Harden-Barrios J, Ulep R, Luo Q. eHealth Literacy: Patient Engagement in Identifying Strategies to Encourage Use of Patient Portals Among Older Adults. Popul Health Manag 2017 Dec;20(6):486-494. [doi: 10.1089/pop.2016.0164] [Medline: 28384076]

26. Ronda MCM, Dijkhorst-Oei L, Rutten GEHM. Reasons and barriers for using a patient portal: survey among patients with diabetes mellitus. J Med Internet Res 2014 Nov 25;16(11):e263 [FREE Full text] [doi: 10.2196/jmir.3457] [Medline: 25424228]

27. Smith SG, O'Conor R, Aitken W, Curtis LM, Wolf MS, Goel MS. Disparities in registration and use of an online patient portal among older adults: findings from the LitCog cohort. J Am Med Inform Assoc 2015 Jul 25;22(4):888-895 [FREE Full text] [doi: 10.1093/jamia/ocv025] [Medline: 25914099]

28. Tsai R, Bell EJ, Woo H, Baldwin K, Pfeffer MA. How Patients Use a Patient Portal: An Institutional Case Study of Demographics and Usage Patterns. Appl Clin Inform 2019 Jan;10(1):96-102 [FREE Full text] [doi: 10.1055/s-0038-1677528] [Medline: $\underline{\text { 30727003] }}$

29. Turvey C, Klein D, Fix G, Hogan TP, Woods S, Simon SR, et al. Blue Button use by patients to access and share health record information using the Department of Veterans Affairs' online patient portal. J Am Med Inform Assoc 2014 Jul 01;21(4):657-663 [FREE Full text] [doi: 10.1136/amiajnl-2014-002723] [Medline: 24740865]

30. Wedd J, Basu M, Curtis LM, Smith K, Lo DJ, Serper M, et al. Racial, Ethnic, and Socioeconomic Disparities in Web-Based Patient Portal Usage Among Kidney and Liver Transplant Recipients: Cross-Sectional Study. J Med Internet Res 2019 Apr 22;21(4):e11864 [FREE Full text] [doi: 10.2196/11864] [Medline: 31008707] 
31. Abel EA, Shimada SL, Wang K, Ramsey C, Skanderson M, Erdos J, et al. Dual Use of a Patient Portal and Clinical Video Telehealth by Veterans with Mental Health Diagnoses: Retrospective, Cross-Sectional Analysis. J Med Internet Res 2018 Nov 07;20(11):e11350 [FREE Full text] [doi: 10.2196/11350] [Medline: 30404771]

32. Fiks AG, DuRivage N, Mayne SL, Finch S, Ross ME, Giacomini K, et al. Adoption of a Portal for the Primary Care Management of Pediatric Asthma: A Mixed-Methods Implementation Study. J Med Internet Res 2016 Jun 29;18(6):e172 [FREE Full text] [doi: 10.2196/jmir.5610] [Medline: 27357835]

33. Krist AH, Woolf SH, Bello GA, Sabo RT, Longo DR, Kashiri P, et al. Engaging primary care patients to use a patient-centered personal health record. Ann Fam Med 2014;12(5):418-426 [ [FREE Full text] [doi: 10.1370/afm.1691] [Medline: 25354405]

34. Ancker J, Mauer E, Kalish R, Vest J, Gossey J. Early Adopters of Patient-Generated Health Data Upload in an Electronic Patient Portal. Appl Clin Inform 2019 Mar 10;10(2):254-260 [FREE Full text] [doi: 10.1055/s-0039-1683987] [Medline: 30970383]

35. Kipping S, Stuckey MI, Hernandez A, Nguyen T, Riahi S. A Web-Based Patient Portal for Mental Health Care: Benefits Evaluation. J Med Internet Res 2016 Nov 16;18(11):e294 [FREE Full text] [doi: 10.2196/jmir.6483] [Medline: 27852556]

36. Lau M, Campbell H, Tang T, Thompson DJS, Elliott T. Impact of patient use of an online patient portal on diabetes outcomes. Can J Diabetes 2014 Feb;38(1):17-21. [doi: 10.1016/j.jcjd.2013.10.005] [Medline: 24485208]

37. Manard W, Scherrer JF, Salas J, Schneider FD. Patient Portal Use and Blood Pressure Control in Newly Diagnosed Hypertension. J Am Board Fam Med 2016;29(4):452-459 [FREE Full text] [doi: 10.3122/jabfm.2016.04.160008] [Medline: $\underline{27390376]}$

38. North F, Crane SJ, Chaudhry R, Ebbert JO, Ytterberg K, Tulledge-Scheitel SM, et al. Impact of patient portal secure messages and electronic visits on adult primary care office visits. Telemed J E Health 2014 Mar;20(3):192-198 [FREE Full text] [doi: 10.1089/tmj.2013.0097] [Medline: 24350803]

39. Plate JF, Ryan SP, Bergen MA, Hong CS, Attarian DE, Seyler TM. Utilization of an Electronic Patient Portal Following Total Joint Arthroplasty Does Not Decrease Readmissions. J Arthroplasty 2019 Feb;34(2):211-214. [doi: 10.1016/j.arth.2018.11.002] [Medline: 30497899]

40. Powell KR, Deroche C. Predictors and patterns of portal use in patients with multiple chronic conditions. Chronic Illn 2020 Dec;16(4):275-283. [doi: 10.1177/1742395318803663] [Medline: $\underline{30284917]}$

41. Sun R, Burke LE, Saul MI, Korytkowski MT, Li D, Sereika SM. Use of a Patient Portal for Engaging Patients with Type 2 Diabetes: Patterns and Prediction. Diabetes Technol Ther 2019 Oct;21(10):546-556. [doi: 10.1089/dia.2019.0074] [Medline: $\underline{\text { 31335206] }}$

42. Zhong X, Liang M, Sanchez R, Yu M, Budd PR, Sprague JL, et al. On the effect of electronic patient portal on primary care utilization and appointment adherence. BMC Med Inform Decis Mak 2018 Oct 16;18(1):84-12 [FREE Full text] [doi: 10.1186/s12911-018-0669-8] [Medline: 30326876]

43. Foster B, Krasowski MD. The Use of an Electronic Health Record Patient Portal to Access Diagnostic Test Results by Emergency Patients at an Academic Medical Center: Retrospective Study. J Med Internet Res 2019 Jun 28;21(6):e13791 [FREE Full text] [doi: 10.2196/13791] [Medline: $\underline{\text { 31254335] }}$

44. Griffin A, Skinner A, Thornhill J, Weinberger M. Patient Portals: Who uses them? What features do they use? And do they reduce hospital readmissions? Appl Clin Inform 2016;7(2):489-501 [FREE Full text] [doi: 10.4338/ACI-2016-01-RA-0003] [Medline: 27437056]

45. Huang J, Chen Y, Landis JR, Mahoney KB. Difference Between Users and Nonusers of a Patient Portal in Health Behaviors and Outcomes: Retrospective Cohort Study. J Med Internet Res 2019 Oct 07;21(10):e13146 [FREE Full text] [doi: 10.2196/13146] [Medline: $\underline{31593546}$ ]

46. Jhamb M, Cavanaugh KL, Bian A, Chen G, Ikizler TA, Unruh ML, et al. Disparities in Electronic Health Record Patient Portal Use in Nephrology Clinics. Clin J Am Soc Nephrol 2015 Nov 06;10(11):2013-2022 [FREE Full text] [doi: 10.2215/CJN.01640215] [Medline: 26493242]

47. Bajracharya A, Crotty B, Kowoloff H, Safran C, Slack WV. Patient experience with family history tool: analysis of patients' experience sharing their family health history through patient-computer dialogue in a patient portal. J Am Med Inform Assoc 2019 Jul 01;26(7):603-609 [FREE Full text] [doi: 10.1093/jamia/ocz008] [Medline: 30946464]

48. Bidmead E, Marshall A. A case study of stakeholder perceptions of patient held records: the Patients Know Best (PKB) solution. Digit Health 2016 Sep 21;2:2055207616668431-2055207616668415 [FREE Full text] [doi: 10.1177/2055207616668431] [Medline: 29942567]

49. Jahn MA, Porter BW, Patel H, Zillich AJ, Simon SR, Russ AL. Usability Assessment of Secure Messaging for Clinical Document Sharing between Health Care Providers and Patients. Appl Clin Inform 2018 Apr;9(2):467-477 [FREE Full text] [doi: 10.1055/s-0038-1660521] [Medline: 29949815]

50. King G, Maxwell J, Karmali A, Hagens S, Pinto M, Williams L, et al. Connecting Families to Their Health Record and Care Team: The Use, Utility, and Impact of a Client/Family Health Portal at a Children's Rehabilitation Hospital. J Med Internet Res 2017 Apr 06;19(4):e97 [FREE Full text] [doi: 10.2196/jmir.6811] [Medline: 28385680]

51. Mishuris RG, Stewart M, Fix GM, Marcello T, McInnes DK, Hogan TP, et al. Barriers to patient portal access among veterans receiving home-based primary care: a qualitative study. Health Expect 2015 Dec 12;18(6):2296-2305 [FREE Full text] [doi: 10.1111/hex.12199] [Medline: 24816246] 
52. Portz JD, Bayliss EA, Bull S, Boxer RS, Bekelman DB, Gleason K, et al. Using the Technology Acceptance Model to Explore User Experience, Intent to Use, and Use Behavior of a Patient Portal Among Older Adults With Multiple Chronic Conditions: Descriptive Qualitative Study. J Med Internet Res 2019 Apr 08;21(4):e11604 [FREE Full text] [doi: 10.2196/11604] [Medline: 30958272]

53. Schultz CL, Alderfer MA. Are on-line patient portals meeting test result preferences of caregivers of children with cancer? A qualitative exploration. Pediatr Blood Cancer 2018 Nov 14;65(11):e27306. [doi: 10.1002/pbc.27306] [Medline: 30007016]

54. Quanbeck A, Gustafson DH, Marsch LA, Chih M, Kornfield R, McTavish F, et al. Implementing a Mobile Health System to Integrate the Treatment of Addiction Into Primary Care: A Hybrid Implementation-Effectiveness Study. J Med Internet Res 2018 Jan 30;20(1):e37 [FREE Full text] [doi: 10.2196/jmir.8928] [Medline: 29382624]

55. Riippa I, Linna M, Rönkkö I. A Patient Portal With Electronic Messaging: Controlled Before-and-After Study. J Med Internet Res 2015 Nov 09;17(11):e250 [FREE Full text] [doi: 10.2196/jmir.4487] [Medline: 26553595]

56. Riippa I, Linna M, Rönkkö I. The effect of a patient portal with electronic messaging on patient activation among chronically ill patients: controlled before-and-after study. J Med Internet Res 2014 Nov 19;16(11):e257 [FREE Full text] [doi: 10.2196/jmir.3462] [Medline: 25413368]

57. van der Vaart R, Drossaert CHC, Taal E, Drossaers-Bakker KW, Vonkeman HE, van de Laar MAFJ. Impact of patient-accessible electronic medical records in rheumatology: use, satisfaction and effects on empowerment among patients. BMC Musculoskelet Disord 2014 Mar 26;15:102 [FREE Full text] [doi: 10.1186/1471-2474-15-102] [Medline: 24673997]

58. Wallace LS, Angier H, Huguet N, Gaudino JA, Krist A, Dearing M, et al. Patterns of Electronic Portal Use among Vulnerable Patients in a Nationwide Practice-based Research Network: From the OCHIN Practice-based Research Network (PBRN). J Am Board Fam Med 2016 Oct;29(5):592-603 [FREE Full text] [doi: 10.3122/jabfm.2016.05.160046] [Medline: 27613792]

59. Gossec L, Cantagrel A, Soubrier M, Berthelot J, Joubert J, Combe B, et al. An e-health interactive self-assessment website (Sanoia) in rheumatoid arthritis. A 12-month randomized controlled trial in 320 patients. Joint Bone Spine 2018 Dec;85(6):709-714. [doi: 10.1016/j.jbspin.2017.11.015] [Medline: 29246532]

60. Fiks AG, Mayne SL, Karavite DJ, Suh A, O'Hara R, Localio AR, et al. Parent-reported outcomes of a shared decision-making portal in asthma: a practice-based RCT. Pediatrics 2015 Apr;135(4):e965-e973 [FREE Full text] [doi: 10.1542/peds.2014-3167] [Medline: 25755233]

61. Stein JN, Klein JW, Payne TH, Jackson SL, Peacock S, Oster NV, et al. Communicating with Vulnerable Patient Populations: A Randomized Intervention to Teach Inpatients to Use the Electronic Patient Portal. Appl Clin Inform 2018 Oct;9(4):875-883 [FREE Full text] [doi: 10.1055/s-0038-1676333] [Medline: 30541152]

62. Sakaguchi-Tang DK, Bosold AL, Choi YK, Turner AM. Patient Portal Use and Experience Among Older Adults: Systematic Review. JMIR Med Inform 2017 Oct 16;5(4):e38 [FREE Full text] [doi: 10.2196/medinform.8092] [Medline: 29038093]

63. Zhao JY, Song B, Anand E, Schwartz D, Panesar M, Jackson GP, et al. Barriers, Facilitators, and Solutions to Optimal Patient Portal and Personal Health Record Use: A Systematic Review of the Literature. AMIA Annu Symp Proc 2017;2017:1913-1922 [FREE Full text] [Medline: 29854263]

64. Kruse CS, Argueta DA, Lopez L, Nair A. Patient and provider attitudes toward the use of patient portals for the management of chronic disease: a systematic review. J Med Internet Res 2015 Feb 20;17(2):e40 [FRE Full text] [doi: 10.2196/jmir.3703] [Medline: 25707035]

65. Giansanti D. Cybersecurity and the : The Challenge of This Millennium. Healthcare (Basel) 2021 Jan 11;9(1):62 [REE Full text] [doi: 10.3390/healthcare9010062] [Medline: 33440612]

\section{Abbreviations}

ED: emergency department

EMR: electronic medical record

ER: emergency room

RCT: randomized controlled trial

Edited by R Kukafka; submitted 03.12.20; peer-reviewed by S Pillon, N Gordon, I Wilson, F Kaliyadan; comments to author 10.01.21;
revised version received 24.01.21; accepted 24.05.21; published 08.09.21
Please cite as:
Carini E, Villani L, Pezzullo AM, Gentili A, Barbara A, Ricciardi W, Boccia S
The Impact of Digital Patient Portals on Health Outcomes, System Efficiency, and Patient Attitudes: Updated Systematic Literature
Review
J Med Internet Res 2021;23(9):e26189
URL: https://www.jmir.org/2021/9/e26189
doi: $10.2196 / 26189$
PMID:


(CElettra Carini, Leonardo Villani, Angelo Maria Pezzullo, Andrea Gentili, Andrea Barbara, Walter Ricciardi, Stefania Boccia. Originally published in the Journal of Medical Internet Research (https://www.jmir.org), 08.09.2021. This is an open-access article distributed under the terms of the Creative Commons Attribution License (https://creativecommons.org/licenses/by/4.0/), which permits unrestricted use, distribution, and reproduction in any medium, provided the original work, first published in the Journal of Medical Internet Research, is properly cited. The complete bibliographic information, a link to the original publication on https://www.jmir.org/, as well as this copyright and license information must be included. 